\title{
ANALIZA KRYTYCZNA ROZWIĄZAŃ USTAWY Z DNIA 8 CZERWCA 2017 R. O ZMIANIE USTAWY O REGIONALNYCH IZBACH OBRACHUNKOWYCH I NIEKTÓRYCH INNYCH USTAW
}

\section{Wstęp}

Regionalne izby obrachunkowe w obecnym kształcie funkcjonują na podstawie ustawy z dnia 7 października $1992 \mathrm{r}$. o regionalnych izbach obrachunkowych ${ }^{1}$, swoje umocowanie zaś znajdują również w art. 171 ust. 2 Konstytucji Rzeczypospolitej Polskiej². To unormowania Konstytucji RP nadają omawianej instytucji kształt oraz określają reguły ustrojowe funkcjonowania regionalnych izb obrachunkowych. Zwrócić należy uwagę, że ustrojodawca postanowienia dotyczące izb zamieścił w dziale dotyczącym samorządu terytorialnego, a ponadto wyróżnił ich rolę $\mathrm{w}$ kontekście nadzoru nad sprawami finansowymi. Zastosowanie zabiegu „a w zakresie spraw finansowych" świadczy o szczególnym znaczeniu aspektu finansów publicznych sektora samorządowego z punktu widzenia ustrojodawcy. Nadana omawianej instytucji nazwa wskazuje na regionalny charakter, tj. występowanie tego szczególnego organu na poziomie regionalnym. Co więcej, umiejscowienie izb w ramach rozdziału VII Konstytucji wskazuje na ich wyodrębnienie z administracji rządowej (inaczej niż to ma miejsce w przypadku wojewody). Tym samym izby stanowią organ o charakterze pośrednim pomiędzy organami administracji

* Doktorant na Wydziale Prawa i Administracji Uniwersytetu Szczecińskiego; e-mail: dawid.czesyk@wp.pl, https:/ / orcid.org/0000-0002-0164-9296.

1 Ustawa z dnia 7 października 1992 r. o regionalnych izbach obrachunkowych, tekst jednolity: Dz. U. z 2016 r. poz. 561 (dalej: u.r.i.o.).

2 Konstytucja Rzeczypospolitej Polskiej z dnia 2 kwietnia 1997 r., Dz. U. Nr 78, poz. 483 z późn. zm. 
rządowej (z niej wyodrębnionej i niezależnej) oraz samorządu terytorialnego ${ }^{3}$. W ujęciu historycznym kształt przedstawianego organu nadzoru oparty został na rozwiązaniach francuskich. We Francji, która podobnie jak Polska jest państwem unitarnym, za nadzór nad gospodarowaniem środkami publicznymi przez samorządy odpowiadają chambreregional des comptes. Izbom tym przysługuje status organów państwowych, których koszt funkcjonowania ponosi państwo. Określane są jako regionalne sądy finansowe, działające $w$ ramach gremiów kolegialnych, a ich pracownicy zaliczani są do urzędników państwowych. Zakres przedmiotowy nadzoru francuskich izb obejmuje wykonywanie budżetu, prawidłowe prowadzenie rachunkowego wykonywania rozliczeń finansowych, a także analiza budżetów jednostek publicznych działających na obszarze regionów $\mathrm{w}$ kraju${ }^{4}$. Ustawodawca skorzystał z wzorca francuskiego z uwagi na zamiar utrzymania niezależności gmin od aparatu państwowego oraz zasady decentralizacji władzy publicznej. Koncepcja zakładała utworzenie organu, mogącego skutecznie wykonywać zadania związane z nadzorem i kontrolą jednostek samorządu terytorialnego (dalej: JST), a jednocześnie pozostającego częścią administracji niezależną „ustrojowo" od państwa, samodzielnego i realizującego zadania publiczne w imieniu własnym i na własną odpowiedzialność ${ }^{5}$.

Izby nie stanowią organów wyższej instancji w rozumieniu przepisów postępowania administracyjnego, jak i podatkowego. Nie rozstrzygają indywidualnych spraw administracyjnych. Andrzej Skibiński wskazuje, że regionalne izby obrachunkowe jako organy terenowej administracji stanowią przykład administracji nowego typu w polskim systemie podmiotów administracji publicznej o nietypowym i wyspecjalizowanym charakterze ${ }^{6}$.

Izby [...] są organem „pośrednim”, równoważącym działalność państwa i samorządu terytorialnego oraz ich wzajemne wpływy. Całokształt pozycji prawnej i zadań izb prowadzi do uznania ich podwójnej roli - jako podmiotu działającego wobec państwa na rzecz samorządów i w ich interesie zgodnie

3 Podobnie K. Sawicka, w: W. Miemiec, K. Sawicka, M. Miemiec, Prawo finansów publicznych sektora samorzadowego, Warszawa 2013, s. 245.

4 A. Skibiński, Regionalne Izby Obrachunkowe i Samorządowe Kolegia Odwoławcze typowe organy administracji czy wyspecjalizowana administracja wojewódzka, PWSZ IPiA Studia Lubuskie 2008, t. 4, s. 165-166.

5 Tamże, s. 166.

6 Tamże, s. 168. 
z zasadą subsydiarności oraz podmiotu wykonującego funkcje państwowe wobec samorządu terytorialnego w imieniu i na rachunek państwa7

Z kolei Jan Tarno stwierdza, że w odniesieniu do izb obrachunkowych zasadne jest twierdzenie, że są to takie organy, które równoważą działalność państwa i samorządu terytorialnego. Ich pozycja ustrojowa i zadania skłaniają do uznania ich jako podmioty działające wobec samorządu terytorialnego, ale zawsze w imieniu i na rachunek państwa. To pozwala na postawienie tezy, iż organy te stanowią uzupełnienie i dopełnienie organów samorządu terytorialnego ${ }^{8}$. Zdaniem Teresy Dębowskiej-Romanowskiej regionalne izby obrachunkowe stanowią rodzaj quasi-sądownictwa finansowego w odniesieniu do lokalnej działalności komunalnej, któremu przysługuje również przymiot niezawisłości ${ }^{9}$. Autorka stwierdza również, że postanowienia Konstytucji RP determinują charakter organu nadzoru, jakim są regionalne izby obrachunkowe. Izby muszą być zbudowane w sposób gwarantujący udział przedstawicieli środowisk samorządowych w ich składzie osobowym, działalność orzecznicza składów orzekających musi być niezawisła, a w konsekwencji izby muszą być niezależne od władzy wykonawczej w zakresie wykonywania funkcji nadzorczych i kontrolnych ${ }^{10}$. Co więcej, Dębowska-Romanowska wskazuje, że izby muszą być organem hybrydalnym.

[...] będąc państwowym organem kontroli i nadzoru, nie mogą być organem administracji rządowej, podległym organizacyjnie i funkcjonalnie Radze Ministrów w zakresie sprawowania funkcji nadzorczych i kontrolnych. Muszą zachować pewne cechy sądu finansowego, zwłaszcza jeśli chodzi o niezależność członków kolegiów w trakcie orzekania ${ }^{11}$.

7 Tamże, s. 169.

8 J.P. Tarno, Dwuinstancyjność w systemie organów samorządu terytorialnego, Miejsce i rola RIO i SKO w systemie samorządu terytorialnego, Ogólnopolska Konferencja Naukowa, Uniwersytet Zielonogórski, Zielona Góra 2005, s. 26-27.

9 T. Dębowska-Romanowska, Nadzór nad działalnością komunalna w zakresie spraw budżetowych, kontrola gospodarki finansowej gmin, w: Samorząd terytorialny i rozwój lokalny, red. A. Piekara, Z. Niewiadomski, Warszawa 1996, s. 331; podobnie: B. Dolnicki, Nadzór nad samorzadem terytorialnym, Katowice 1993, s. 144.

10 T. Dębowska-Romanowska, Na dwudziestolecie powstania regionalnych izb obrachunkowych..., w: Samorząd, finanse, nadzór i kontrola. XX-lecie Regionalnych Izb Obrachunkowych, red. R. Krawczyk, M. Stec, Warszawa 2013, s. 17.

11 Tamże. 
Z drugiej zaś strony muszą zapewniać w swoim składzie udział przedstawicieli samorządów, aby były przez te jednostki odbierane jako organy o charakterze pomocniczym ${ }^{12}$. Całokształt pozycji prawnej i zadań izb prowadzi do uznania ich podwójnej roli - jako podmiotu działającego wobec państwa na rzecz samorządów i w ich interesie zgodnie z zasadą subsydiarności oraz podmiotu wykonującego funkcje państwowe wobec samorządu terytorialnego $\mathrm{w}$ imieniu i na rachunek państwa. Funkcje te nie są jednak dychotomiczne i rozłączne, lecz przenikają się wzajemnie ${ }^{13}$. W ocenie Joanny Salachny uwarunkowania konstytucyjne wskazują na szczególną rolę izb w strukturze nadzoru nad finansami JST. Tę szczególną rolę należy wiązać z istotą spraw finansowych jako części działalności samorządów, a także wyodrębnieniem izb ze struktur organów administracji rządowej ${ }^{14}$.

Stosownie do postanowień art. 1 ust. 1 u.r.i.o. regionalne izby obrachunkowe stanowią państwowe organy nadzoru i kontroli gospodarki finansowej JST, ich związków, a także innych podmiotów pokrewnych wskazanych w ust. 2 cytowanego artykułu. W drodze art. 4 u.r.i.o. ustawodawca, biorąc pod uwagę nomenklaturę prawno-finansową, zaliczył izby do państwowych jednostek budżetowych. Stosownie zaś do art. 2 nadzór nad funkcjonowaniem izb sprawuje minister właściwy do spraw administracji publicznej. Kwestie stanowiące przedmiot niniejszego opracowania, tj. ustrój i organizację izb, reguluje rozdział 3 omawianej ustawy. Prawodawca w drodze art. 14 postanowił, że organem izby jest kolegium, któremu przewodniczy prezes izby, a jego skład uzupełniają pozostali członkowie kolegium. W myśl art. 16 ust. 1 u.r.i.o. prezesa izby powołuje Prezes Rady Ministrów na wniosek ministra właściwego do spraw administracji publicznej. Wskazać jednak należy, że powołanie przewodniczącego kolegium przez naczelny organ administracji rządowej nie odbywa się $\mathrm{w}$ drodze jego samodzielnej decyzji. Kandydata na stanowisko prezesa wybiera kolegium izby po przeprowadzeniu konkursu. Co istotne, szczegółowe warunki przeprowadzania konkursu na stanowisko prezesa izby określi w drodze rozporządzenia minister właściwy do spraw administracji publicznej. Przywołane rozporządzenie określa zadania komisji

12 Tamże.

13 J.P. Tarno, Naczelny Sąd Administracyjny, a wykładnia prawa administracyjnego, Łódź 1997.

14 J. Salachna, Funkcja ustrojowa regionalnych izb obrachunkowych, Finanse Komunalne 2018, nr 12, s. 8 . 
konkursowej, wzór ogłoszenia o konkursie publikowanym w prasie o zasięgu ogólnokrajowym, termin zgłaszania kandydatów, etapy postępowania konkursowego oraz tryb postępowania odwoławczego od rozstrzygnięcia konkursu przez kolegium izby ${ }^{15}$.

Ustawodawca przesądził jednocześnie, że kadencja prezesa izby trwa 6 lat, licząc od daty powołania przez Prezesa Rady Ministrów. Ponadto przepisy ustawy $\mathrm{w}$ drodze katalogu zamkniętego określają przesłanki determinujące odwołanie prezesa izby z pełnionej funkcji.

W zakresie dotyczącym wyboru oraz powołania pozostałych członków kolegium izby warunki i tryb są niemal analogiczne jak na stanowisko prezesa izby. Zgodnie z art. 15 ust. 2 u.r.i.o. członków kolegium powołuje Prezes Rady Ministrów na wniosek prezesa danej izby, po uzyskaniu opinii kolegium izby w zakresie dotyczącym określonego kandydata. Warunki formalne kandydata ubiegającego się o powołanie do organu kolegialnego izby są takie same jak $\mathrm{w}$ przypadku kandydatów na stanowisko prezesa. Szczegółowe warunki oraz tryb przeprowadzania konkursu określa $\mathrm{w}$ drodze rozporządzenia minister właściwy do spraw administracji publicznej ${ }^{16}$. Co istotne z punktu widzenia składu osobowego kolegium izby, prawodawca $\mathrm{w}$ drodze art. 15 ust. 3 postanowił, że połowę składu organu izby stanowią członkowie powołani spośród kandydatów zgłoszonych przez organy stanowiące JST danego województwa. Tym samym zachowano warunek udziału przedstawicieli samorządów w działalności nadzorczej. Ponadto ustawodawca przewidział dwojaki charakter członkostwa w kolegium izby: etatowy oraz pozaetatowy. Etatowy członek kolegium powoływany jest na czas nieokreślony, natomiast pozaetatowy na 6-letnią kadencję. Przesłanki odwołania członków kolegium, bez względu na charakter, są tożsame jak w przypadku stanowiska prezesa izby. Ustawodawca w drodze art. 15 ust. 7 u.r.i.o. podkreślił, że członkowie kolegium w zakresie realizacji zadań nadzorczych i funkcji kontrolnych są niezawiśli i podlegają jedynie ustawom. A zatem powinni być wolni od wszelkich nacisków ze strony zarówno samorządowej, jak i rządowej. W nauce prawa finansowego wskazuje się, że tryb powoływania

15 Rozporządzenie Ministra Spraw Wewnętrznych i Administracji z dnia 19 stycznia 2004 r. w sprawie szczegółowych warunków przeprowadzania konkursu na prezesa regionalnej izby obrachunkowej, Dz. U. Nr 10, poz. 93.

16 Rozporządzenie Ministra Spraw Wewnętrznych i Administracji z dnia 23 kwietnia 2004 r. w sprawie szczegółowych warunków przeprowadzania konkursu na członków kolegium regionalnej izby obrachunkowej, Dz. U. Nr 130, poz. 1396 z późn. zm. 
członków kolegium oraz prezesa izby, jak również prawnie ugruntowana ich pozycja stanowią gwarancje niezależności izb od organów władzy wykonawczej ${ }^{17}$.

Na mocy art. 18 ust. 1 u.r.i.o. ustawodawca określił zakres właściwości kolegium izby, wskazując iż do niego należy m.in.: ustalanie budżetu JST oraz orzekanie o nieważności uchwał i zarządzeń należących do właściwości rzeczowej izb, rozpatrywanie odwołań od opinii składów orzekających wskazanych w ustawie.

Członkowie kolegium wykonują również zadania opiniodawcze regionalnych izb obrachunkowych, w ramach trzyosobowych składów orzekających. Przy czym zauważyć należy, że składy orzekające nie posiadają przymiotu organu oraz kompetencji wydawania rozstrzygnięć nadzorczych. W literaturze wskazuje się, że opinie wydawane przez regionalne izby obrachunkowe nie stanowią aktów nadzoru, a wyrażane w nich stanowisko nie ma charakteru wiążącego. Wywierają jednak wpływ na zapewnienie zgodności z prawem uchwał podejmowanych przez organy JST. Opinie nabierają większego znaczenia w przypadku, kiedy podjęcie przez organ stanowiący uchwały musi poprzedzać wydanie przez izbę stosownej opinii co do projektu uchwały. W sytuacji wydania opinii negatywnej rada/sejmik nabywa wiedzę o pojawieniu się w postanowieniach projektu nieprawidłowości mogących stanowić podstawę zastosowania środka nadzoru w postaci stwierdzenia nieważności uchwały ${ }^{18}$.

Biorąc pod uwagę występujące nieprawidłowe zarządzanie finansami publicznymi przez organy JST (przykład zniesionej Gminy Ostrowice), Rada Ministrów, a następnie parlament podjęli próbę dokonania zmian funkcjonowania finansowych organów nadzoru nad JST. W dniu 8 czerwca 2017 r. parlament uchwalił ustawę o zmianie ustawy o regionalnych izbach obrachunkowych i niektórych innych ustaw, dnia 12 lipca 2017 r. Prezydent RP zaś, korzystając z przysługującej mu prerogatywy, dokonał jej zawetowania. Postanowienia ww. ustawy nie zapewniały realizacji stawianego przez prawodawcę celu. Omawiana ustawa wprowadzała zmiany $\mathrm{w}$ zakresie ustrojowym prawa samorządu terytorialnego oraz prawa administracyjnego, dokonując nowelizacji sposobu powoływania

17 K. Sawicka, w: W. Miemiec, K. Sawicka, M. Miemiec, Prawo finansów publicznych..., s. 246 .

18 M. Ofiarska, Z. Ofiarski, Opinie regionalnych izb obrachunkowych jako narzędzie oddziatywania na organy jednostek samorządu terytorialnego, w: Samorzą, finanse, nadzór..., s. 269. 
członków kolegiów regionalnych izb obrachunkowych. Proponowane zmiany mogły przełożyć się na efektywność zadań nadzorczych przez finansowe organy nadzoru. Ponadto część proponowanych zmian budzi wątpliwości z punktu widzenia ich zgodności z Konstytucją. Niniejsza publikacja stanowi krytyczną analizę proponowanych rozwiązań z punktu widzenia celowości i funkcjonalności regulacji. W publikacji metodą analityczną objęto analizę proponowanych przepisów ustawy nowelizującej dotyczących organizacji i funkcjonowania izb, uwzględniając jednocześnie dorobek literatury przedmiotu. Badając zgodność proponowanych rozwiązań z Konstytucją, poddano analizie orzecznictwo Trybunału Konstytucyjnego, odnosząc się do postawionej w publikacji tezy.

\section{Nowelizacja ustroju regionalnych izb obrachunkowych i jej założenia}

Na przestrzeni ostatnich 25 lat w cytowanej ustawie dokonano kilkunastu nowelizacji, które nie stanowiły rewolucji w zakresie ustroju i organizacji regionalnych izb obrachunkowych. W 2016 r. rozpoczęto prace nad projektem nowelizacji ustawy o regionalnych izbach obrachunkowych. W dniu 15 lipca 2016 r. opublikowano projekt ustawy nowelizującej ${ }^{19}$. Przedmiotowy projekt został poddany konsultacjom, a finalny efekt prac rządowych datuje się na dzień 14 marca 2017 r. Wówczas Rada Ministrów przyjęła projekt ustawy i zadecydowała o skierowaniu go do Sejmu w celu przeprowadzenia dalszych prac legislacyjnych. Projekt ustawy został złożony w dniu 16 marca 2017 r. i otrzymał druk nr 1409. Regulacje przygotowane przez rząd w ocenie projektodawcy miały pozwolić na skuteczniejsze przeciwdziałanie nadmiernego zadłużania się samorządów, co w konsekwencji wzmocni ich pozycję gospodarczą. Rozwiązania natury ustrojowej i organizacyjnej przygotowane w projekcie miały przyczynić się do zwiększenia skuteczności działań nadzorczych i kontrolnych wobec jednostek samorządu terytorialnego. Z uzasadnienia projektu wynika również, że zadłużenie jednostek samorządu terytorialnego determinuje konieczność modyfikacji kompetencji, a także rozwiązań ustrojowych

19 Legislacja.rcl.gov.pl. 
dotyczących funkcjonowania regionalnych izb obrachunkowych przez „uporządkowanie i uszczelnienie uprawnień kontrolnych" 20 .

Pierwsze czytanie projektu odbyło się w dniu 7 kwietnia 2017 r., na którym izba niższa parlamentu zadecydowała o skierowaniu projektu do dalszych prac legislacyjnych przez komisję sejmową. Dnia 8 czerwca 2017 r. odbyło się drugie i trzecie czytanie projektu ustawy, a następnie ustawa została uchwalona. Senat ustawę bez poprawek przyjął w dniu 22 czerwca $2017 \mathrm{r}$.

Należy w tym miejscu wskazać, że treść uchwalonej przez parlament ustawy różni się od projektu wniesionego przez Radę Ministrów.

Przyjęta przez parlament ustawa stanowiła rewolucję, biorąc pod uwagę ustrój i organizację regionalnych izb obrachunkowych. W dniu 12 lipca 2017 r. Prezydent RP, na podstawie prerogatywy wyrażonej w drodze art. 122 ust. 5 Konstytucji, odmówił podpisania ww. ustawy i skierował ją do dalszych prac parlamentu.

U podstaw decyzji prezydenta legła kwestia całokształtu proponowanych przez parlament rozwiązań. Począwszy od dodania kryterium nadzoru nad JST w postaci kryterium gospodarności, po podporządkowanie składu osobowego organu izby Prezesowi Rady Ministrów, a także możliwość nadania rygoru natychmiastowej wykonalności rozstrzygnięciu Prezesa Rady Ministrów o odwołaniu wójta/burmistrza/prezydenta miasta lub rozwiązaniu zarządu powiatu/województwa oraz zawieszeniu organów JST. W uzasadnieniu zastosowanej prerogatywy Prezydent wskazał

Zastrzeżenia wobec ustawy z dnia 8 czerwca 2017 r. o zmianie ustawy o regionalnych izbach obrachunkowych oraz niektórych innych ustaw wzmacniają inne regulacje wprowadzone $\mathrm{w}$ trakcie prac parlamentarnych, takie jak: zniesienie procedury konkursowej przy wyłanianiu prezesów i członków kolegiów regionalnych izb obrachunkowych, przyznanie Prezesowi Rady Ministrów swobody powoływania i odwoływania prezesów izb a za pośrednictwem tychże prezesów pozostałych członków kolegiów, rezygnacja z instytucji pozaetatowych członków kolegium izb oraz zniesienie zasady parytetu samorządu terytorialnego w wyłanianiu członków kolegium izby. [...] Uzależnienie składu kolegiów regionalnych izb obrachunkowych od decyzji Prezesa Rady Ministrów, a następnie przyznanie opiniom tak powołanych organów mocy inicjowania odwołania lub zawieszenia wyłonionych

20 Uzasadnienie projektu ustawy o zmianie ustawy o regionalnych izbach obrachunkowych i niektórych innych ustaw, http:/ / www.sejm.gov.pl/Sejm8.nsf/druk.xsp?nr=1409 [dostęp: 4.01.2018 r.]. 
w wyborach powszechnych organów samorządu terytorialnego, może wzbudzać wątpliwości natury systemowej w odniesieniu do ustrojowego usytuowania samorządu terytorialnego ${ }^{21}$.

Postanowienia ustawy uchwalonej przez parlament przewidywały rozwiązania, w drodze których Prezes Rady Ministrów uzyskałby instrumenty umożliwiające realny wpływ na skład osobowy i obsadę członków kolegiów izb (w tym prezesów izb), na których opiera się działalność orzecznicza i nadzorcza finansowych organów nadzoru nad JST.

Przyjęta przez parlament nowelizacja ustawy proponowała zmianę brzmienia art. 2 ust. 1 u.r.i.o., dokonując rewizji zakresu nadzoru sprawowanego przez ministra właściwego do spraw administracji publicznej. W obowiązującej dotychczas ustawie nadzór ten miał wymiar ogólny na podstawie kryterium zgodności z prawem. Natomiast w omawianej ustawie dokonano zmiany tego zakresu, uszczegóławiając go w ten sposób, że nadzór ten dotyczy tylko działalności administracyjnej izby. W uzasadnieniu do rządowego projektu ustawy wskazano, że przedmiotowa poprawka ma charakter jedynie porządkowy, albowiem w społeczeństwie oraz administracji publicznej sektora samorządowego panuje mylne przekonanie o sprawowaniu przez ministra nadzoru nad całym spektrum działalności izb. Tymczasem regionalne izby obrachunkowe znajdują się poza strukturą administracji rządowej. Minister właściwy do spraw administracji publicznej oraz Prezes Rady Ministrów biorą jedynie udział w powoływaniu prezesów izb oraz członków kolegiów, jednak nie przysługują im żadne uprawnienia władcze. Przedmiotowa kwestia jest niezmiernie istotna $\mathrm{z}$ punktu widzenia dalszych zmian przyjętych przez parlament oraz ich uzasadnienia. Pomimo tego, że znowelizowany przepis wskazywałby w sposób jednoznaczny na sprawowanie nadzoru administracji rządowej nad izbami jedynie w aspekcie funkcjonalnym jako instytucji, nie zaś merytorycznym, to inne postanowienia zawetowanej ustawy wprowadzały odmienne mechanizmy umożliwiające skuteczne oddziaływanie rządu na finansowe organy nadzoru nad JST.

Nowelizacja ustawy zakładała derogowanie z systemu prawnego instytucji nieetatowego członka kolegium. Projektodawca przedmiotową zmianę argumentował stronniczością podejmowanych przez

21 Uzasadnienie do odmowy podpisania ustawy przez Prezydenta RP z dnia 12.07.2017r., http:/ / orka.sejm.gov.pl/Druki8ka.nsf/0/50D05A87AB4A7F4CC1258161002FFFC3/\%24 File/1749.pdf [dostęp: 2.01.2018 r.]. 
nieetatowych członków kolegium decyzji w sprawach związanych $\mathrm{np}$. z zastrzeżeniami do wystąpień pokontrolnych kontrolowanych przez izby jednostek. Udział w głosowaniu nad zastrzeżeniami do wniosków pokontrolnych członka kolegium, który brał udział w ich opracowywaniu, może budzić uzasadnione wątpliwości. $W$ takiej sytuacji zasadne byłoby zastosowanie zabiegu legislacyjnego, w ramach którego uniemożliwiono by udziału w głosowaniu takiego członka kolegium. Derogowanie zaś z systemu prawnego instytucji nieetatowego członka kolegium pozbawia de facto możliwości członkostwa w organie nadzoru osób posiadających specjalistyczną wiedzę i doświadczenie, a które nie mogą w pełni oddać się działalności orzeczniczej $\mathrm{w}$ ramach stosunku pracy $\mathrm{w}$ regionalnej izbie obrachunkowej.

Jedną z najważniejszych zmian nowelizacji u.r.i.o. jest zmiana sposobu wyboru prezesów izb oraz członków kolegium. Nowelizacja ustawy, zamiast dotychczasowej procedury konkursowej, zakładała powołanie prezesa izby oraz pozostałych członków kolegium przez Prezesa Rady Ministrów, bez uprzedniego postępowania weryfikującego posiadane kompetencje. A zatem skład kolegium izby wybierany i powoływany byłby przez Prezesa Rady Ministrów. Wobec powyższego regionalne izby obrachunkowe stałyby się organem podległym centralnym organom administracji rządowej nie tylko w aspekcie funkcjonalnym, ale i osobowym. Prezes Rady Ministrów uzyskałby istotny wpływ na kształt osobowy organu nadzoru, a tym samym możliwie silny sposób oddziaływania na JST, już nie tylko w aspekcie nadzoru ogólnego, ale i finansowego.

Należy także zauważyć, że obecna ustawa zawiera przesłanki odwołania prezesów izb oraz członków kolegium, natomiast nowelizacja ich nie zawierała. Proponowane więc rozwiązania wprowadzały w pewnym zakresie możliwość odwołania ww. funkcjonariuszy bez wystąpienia jakichkolwiek przesłanek. Prezes Rady Ministrów pozyskałby kompetencję do jednostronnego decydowania o powoływaniu i odwoływaniu poszczególnych członków organu kolegialnego izby, w tym jego przewodniczącego.

Zauważyć należy, że projektodawca w uzasadnieniu do projektu ustawy wskazał wprost, iż izby stanowią organy niezależne od organów władzy rządowej ${ }^{22}$. A jednak przyjęte przez parlament rozwiązania przeczą powyższej tezie w sposób jednoznaczny. Owszem w sposób literalny izby pozostawałyby organami autonomicznymi w stosunku do administracji

22 Uzasadnienie do projektu ustawy, Legislacja.rcl.gov.pl. 
rządowej, jednak umożliwienie kształtowania składu osobowego organu nadzoru tej niezależności izby pozbawia. Regionalne izby obrachunkowe zostały umiejscowione $\mathrm{w}$ Konstytucji RP w rozdziale poświęconym samorządowi terytorialnemu, a zatem należy je utożsamiać właśnie przez samorząd, a nie przez administrację rządową. Izby nie są zaliczane do struktur rządowych, tym samym sposób wybierania organów przez rząd byłby w mojej ocenie nieuprawniony.

Kolejną zmianą związaną z kształtem osobowym organu izb jest wprowadzenie kadencyjności pełnienia funkcji członka kolegium. Długość kadencji byłaby jednakowa zarówno dla prezesa izby oraz pozostałych członków i wynosiłaby 6 lat. Co więcej, ograniczono możliwość reelekcji na stanowisku prezesa do dwóch następujących po sobie kadencji. Zaproponowane przez ustawodawcę rozwiązanie mogłoby spowodować dużą rotację pracowników izb, co w konsekwencji z pewnością odbiłoby się na jakości podejmowanych rozstrzygnięć nadzorczych oraz wydawanych opinii.

Niezmiernie istotną zmianą zaproponowaną przez prawodawcę jest odmienny sposób wykonywania przez izby kompetencji nadzorczej, tj. podejmowania uchwał w sprawie stwierdzenia nieważności uchwał i zarządzeń JST, ich związków oraz podmiotów wskazanych w ustawie. W obecnym stanie prawnym kompetencję tę posiada wyłącznie kolegium izby. Ustawodawca proponował przyznać przedmiotową kompetencję nadzorczą składom orzekającym na wzór składów orzekających Samorządowych Kolegiów Odwoławczych (dalej: SKO). Krajowa Rada Regionalnych Izb Obrachunkowych (dalej: KRRIO) w toku procesu legislacyjnego wskazywała, że proponowane zmiany nie stanowią wiernego odwzorowania postanowień ustawy o samorządowych kolegiach odwoławczych, w których ustawodawca określił wprost, że posiedzeniom składów orzekających przewodniczy prezes, który posiada status organu, lub etatowy członek kolegium. KRRIO podniosła, iż nie jest wiadome, czy składy orzekające $\mathrm{w}$ ramach kompetencji nadzorczych działać będą w imieniu kolegium izby czy całej izby. Nie określono, czy w ramach izby funkcjonuje jeden organ nadzoru w postaci kolegium, czy jest ich kilka, kto będzie reprezentował składy orzekające przed sądami administracyjnymi w przypadku skarg na rozstrzygnięcia nadzorcze, skoro składy nie posiadają przymiotu organów. W zakresie dotyczącym przyznania składom orzekającym kompetencji nadzorczych wątpliwości mogą być związane z wydawaniem przez nie opinii w sprawie uchwał i zarządzeń, które 
następnie przez te same składy będą rozstrzygane. Kwestię problemową w tym zakresie stanowią również aspekty organizacyjne składów orzekających, tj. zapewnienia pomieszczeń umożliwiających orzekanie, protokołowanie posiedzeńn ${ }^{23}$.

Przepisy przejściowe nowelizacji ustawy zakładały wygaśnięcie stosunków pracy prezesów oraz członków kolegiów izb. Zastosowane rozwiązanie stanowić może o naruszeniu norm wynikających z art. 2 Konstytucji RP, zgodnie którym Rzeczpospolita Polska jest demokratycznym państwem prawnym urzeczywistniającym zasadę sprawiedliwości społecznej. Z przywołanej zasady wynika zasada ochrony zaufania obywatela do państwa i stanowionego przez nie prawa. Opiera się ona na prymacie pewności prawa, który zapewnia jednostce bezpieczeństwo prawne, umożliwiając jej decydowanie o swoim postępowaniu na podstawie znajomości przesłanek działania organów państwa oraz konsekwencji, jakie wywołuje działanie tych organów. Z powyższej zasady wynika również zasada ochrony praw nabytych, w myśl której ustawodawca powinien chronić prawa i wartości nabyte przez obywateli w dotychczasowym stanie prawnym, a nie przyczyniać się do ich wyzbycia. Skoro zatem na podstawie obowiązującego prawa zostały przyznane uprawnienia do piastowania stanowiska prezesa oraz nieetatowych członków kolegium przez okres 6-letniej kadencji, to ich arbitralne skrócenie tę zasadę bezsprzecznie narusza. W wyroku z dnia 12 lipca 2011 r. Trybunał Konstytucyjny stwierdził

[...] ograniczenie bezpieczeństwa prawnego i pewności prawa z powodu ingerencji $\mathrm{w}$ stosunki pracownicze, [...] winno się dokonywać z poszanowaniem niezbędnych gwarancji bezpieczeństwa prawnego osób, których zaskarżone regulacje dotyczą, gwarancji, które wykluczają arbitralność decydentów i nadmierną dolegliwość ograniczeń ${ }^{24}$.

Ponadto proponowane rozwiązania legislacyjne budzą wątpliwość co do zgodności z art. 24 Konstytucji, który stanowi, że stosunek pracy znajduje się pod ochroną Rzeczypospolitej Polskiej. W orzecznictwie

23 Pismo Przewodniczącej KRRIO z dnia 2 czerwca 2017 r., znak: KRRIO-0718/ $\mathrm{I} / 14 / 2017$.

24 Wyrok TK z dnia 12 lipca 2011 r., K 26/09, LEX nr 963651, por. wyrok TK z dnia 24 października 2017 r., K 1/17, LEX nr 2378277, zob. również wyrok TK z dnia 16 czerwca 2003 r., K52/02, LEX nr 80197. 
Trybunału Konstytucyjnego wskazuje się, że art. 24 wyznacza obowiązek państwa do stwarzania gwarancji ochrony pracowników, w tym ochrony przed niezgodnymi z prawem lub nieuzasadnionymi działaniami pracodawcy, jak również przestrzegania przepisów prawa pracy ${ }^{25}$. Tymczasem zaproponowane poprawki ustawy nowelizującej stoją $\mathrm{w}$ sprzeczności z powyższym wzorcem konstytucyjnym. Co więcej, zdaniem Trybunału Konstytucyjnego wygaszenie stosunku pracy ex lege jest możliwe do zastosowania przez prawodawcę, jednak tylko i wyłącznie w drodze wyjątku. Takim wyjątkiem była reforma administracji publicznej w 1999 r. Z kolei w postanowieniu z dnia 31 stycznia 2001 r. Trybunał orzekł, iż zastosowanie wygaśnięcia stosunku pracy $\mathrm{z}$ mocy prawa stanowi instytucję nadzwyczajną $\mathrm{w}$ stosunku do uregulowań przyjętych na gruncie Kodeksu pracy, a tym samym usprawiedliwieniem zastosowania tego typu rozwiązań mogą być nadzwyczajne okoliczności ${ }^{26}$. Natomiast w wyroku z dnia 13 marca 2000 r. Trybunał oceniając nadzwyczajność i wyjątkowość zasady wygaszania stosunków pracy z upływem nadejścia określonego terminu, stwierdził, że ustawodawca nie powinien jej stosować, gdy nie usprawiedliwia tego potrzeba zabezpieczenia innych niż ochrona pracy, konkurencyjnych wartości konstytucyjnych ${ }^{27}$. Nowelizacja ustawy o regionalnych izbach obrachunkowych z 2017 r. nie stanowiła reformy administracji publicznej $\mathrm{w}$ aspekcie kompleksowym, jak to miało miejsce w 1999 r., a zatem zastosowanie rozwiązań prawnych stojących w bezpośrednich kolizji z obowiązkiem państwa do ochrony stosunków pracy wykraczało poza dopuszczalny zakres stanowienia prawa. Co więcej, należy zauważyć, że uchwalenie przepisów w zaproponowanym brzmieniu mogło doprowadzić do wygaszenia stosunków pracy z osobami podlegającymi szczególnej ochronie prawnej, jak np. kobiety w ciąży, na urlopach macierzyńskich - co stanowiłoby naruszenie art. 71 Konstytucji ${ }^{28}$, jak również osób pozostających w przedemerytalnym okresie ochronnym.

${ }^{25}$ Wyrok TK z dnia 4 października 2005 r., K 36/03, LEX nr 165348; wyrok TK z dnia 24 października 2006 r., SK 41/05, LEX nr 210819.

26 Postanowienie TK z dnia 31 stycznia 2001 r., SK 13/00, LEX nr 46006.

27 Wyrok TK z dnia 13 marca 2000 r., K 1/99, LEX nr 39992.

28 Zgodnie z art. 71 ust. 1 Konstytucji RP Państwo w swojej polityce społecznej i gospodarczej uwzględnia dobro rodziny. Rodziny znajdujące się w trudnej sytuacji materialnej i społecznej, zwłaszcza wielodzietne i niepełne, mają prawo do szczególnej pomocy ze strony władz publicznych. 
Jednocześnie zauważyć trzeba, że wygaszenie stosunków pracy z mocy prawa następuje bez oświadczeń woli pracodawcy. Pracodawca, jakim w tym wypadku są regionalne izby obrachunkowe, w imieniu których oświadczenia woli, w zakresie wynikającym ze stosunków pracy, składają prezesi izb, nie ma wpływu na rozwiązanie tych stosunków. A zatem pracownicy zostają pozbawieni narzędzi umożliwiających kontrolę legalności rozwiązania stosunku pracy, a w konsekwencji - konstytucyjnego prawa do sądu wyrażonego w art. 45 ust. 1 Konstytucji RP. Zdaniem Rzecznika Praw Obywatelskich instytucja wygaśnięcia stosunku pracy ogranicza prawo do sądu, ponieważ ogranicza zakres kontroli sądowej wobec pracodawców z uwagi na brak możliwości zbadania przyczyn wygaśnięcia stosunku pracy określonego przez ustawę. W ocenie Trybunału Konstytucyjnego prawo dostępu obywatela do sądu ma charakter zarówno formalny, jak i materialny, który wyznaczony zostaje przez przedmiot określonej sprawy. W przypadku wygaśnięcia stosunku pracy obywatele zostają pozbawieni prawa do sądu właśnie w prawnomaterialnym zakresie ${ }^{29}$.

Na gruncie proponowanych rozwiązań legislacyjnych podać w wątpliwość można również ich zgodność z art. 60 Konstytucji, który zakłada równy dostęp do służby publicznej. Wygaszenie stosunków pracy z prezesami izb oraz członkami kolegium, a następnie arbitralne powołanie prezesów przez Prezesa Rady Ministrów, członków kolegium zaś przez Prezesa Rady Ministrów na wniosek prezesa izby bez przeprowadzenia postępowania konkursowego niewątpliwie ww. zasadę ogranicza. Projektodawca nie określił żadnych kryteriów, którymi Prezes Rady Ministrów oraz prezesi izb będą się kierować podczas powołania członków kolegium, nie wspominając już, że dostęp do służby publicznej dotychczasowym prezesom izb oraz członkom kolegium zostanie ograniczony.

\section{Zakończenie}

Regionalne izby obrachunkowe stanowią finansowe organy nadzoru nad JST. Ich ustrój oraz organizację reguluje ustawa z dnia 7 października 1992 r. o regionalnych izbach obrachunkowych. Finansowe organy nadzoru nad JST w obecnym kształcie funkcjonują od dwudziestu pięciu

\footnotetext{
29 Wyrok TK z dnia 12 lipca 2011 r., K 26/09, LEX nr 963651.
} 
lat. Pełnią one rolę służebną względem JST. Chronią majątek i finanse publiczne, działając w imieniu państwa. Izby posiadają trojaką funkcję nadzorczą, kontrolną oraz informacyjną. W ramach pierwszej z nich istotą jest dbałość o prawidłowe gospodarowanie środkami publicznymi oraz prawidłowa legislacja na poziomie lokalnym. Zadania kontrolne mają wzmocnić nadzór oraz eliminować z życia publicznego zjawiska niepożądane. Natomiast w ramach roli informacyjnej izby udzielają instruktażu, szkoleń oraz szeroko rozumianej pomocy dla samorządów w zakresie dotyczącym prawa finansów publicznych. A zatem rola i zadania izb wskazują na ich wyspecjalizowany charakter, ich pracownicy zaś predestynują do miana specjalistów z dziedziny prawa finansów sektora samorządowego.

Po 25 latach funkcjonowania w dniu 8 czerwca 2017 r. Sejm, a następnie Senat uchwalił nowelizację powyższej ustawy. Nowelizujące przepisy wprowadzały zasadnicze zmiany $w$ ustroju oraz organizacji regionalnych izb obrachunkowych, a także stanowiły o rozwiązaniu z mocy prawa stosunków pracy zatrudnionych w izbach pracowników. Dnia 12 lipca 2017 r. Prezydent RP na podstawie art. 122 ust. 5 Konstytucji RP odmówił podpisania przedmiotowej ustawy i skierował ją do ponownego rozpatrzenia przez parlament. Skorzystanie przez Prezydenta RP z konstytucyjnej prerogatywy uniemożliwiło wejście w życie uchwalonych przez parlament przepisów, co niewątpliwie zapobiegło niekorzystnej ingerencji prawodawcy $\mathrm{w}$ funkcjonujący i budzący dotąd zaufanie system nadzoru nad JST. Intencję projektodawcy stanowiła poprawa funkcjonowania organu nadzoru i jego efektywności. Analiza zaproponowanych rozwiązań sprowadza się do rozwiązania stosunków pracy dotychczasowych członków kolegiów oraz prezesów izb z jednoczesnym przyznaniem kompetencji organom administracji rządowej, powołania nowej kadry. Zaproponowane rozwiązania nie dają podstaw do przyjęcia, że kolegia izb w nowych składach będą wykonywać zadania nadzorcze efektywniej. Ustrój i kształt aktualnie obowiązujących regionalnych izb obrachunkowych zakłada częściowy udział JST w kształtowaniu składu osobowego organu nadzoru, udział zaś ministra właściwego do spraw administracji publicznej oraz Prezesa Rady Ministrów nie ma charakteru władczego. Proponowane w ustawie rozwiązania pozbawiałyby izby przymiotu bezstronności, co mogłoby wpływać na utratę zaufania ze strony nadzorowanych JST, ale także sprawowanie obiektywnego nadzoru. Co więcej, analiza orzecznictwa Trybunału Konstytucyjnego, przywołanego w niniejszym 
artykule, wskazuje na istotne wątpliwości natury konstytucyjnej wynikające z proponowanych rozwiązań prawnych.

Podsumowując niniejszą publikację, należy w pełni zaaprobować słowa Dębowskiej-Romanowskiej odnoszące się do funkcjonowania regionalnych izb obrachunkowych w ramach ustroju samorządu terytorialnego w Rzeczypospolitej Polskiej, które w odniesieniu do omawianej tutaj ustawy nabierają niebagatelnego znaczenia:

Ochrona samodzielności i jej poszanowanie jest obowiązkiem wszystkich władz, ponieważ wyraża dobro wspólne. Stanowi ona interes całego państwa. Dlatego też regionalne izby obrachunkowe mają być wyrazem interesu państwa jako całości, dla którego ochrona samodzielności samorządów w ramach jednolitego i porównywalnego ładu prawnego jest jedną z naczelnych zasad państwa ${ }^{30}$.

Niewątpliwie zmiany $\mathrm{w}$ zakresie funkcjonowania finansowego organu nadzoru są potrzebne. JST korzystają z coraz to nowszych źródeł finansowania oraz metod pozyskiwania środków finansowych. Wobec tego niezbędne jest podjęcie działań legislacyjnych umożliwiających efektywnie wykonywania nadzoru nad samorządami. Niemniej jednak proponowane przez prawodawcę $\mathrm{w}$ drodze ustawy $\mathrm{z}$ dnia 8 czerwca 2017 r. rozwiązania legislacyjne nie przewidywały w gruncie rzeczy rozwiązań prawnych usprawniających wykonywanie powierzonych izbom zadań. Zmiany o charakterze strukturalnym doprowadzić miały do podległości kolegiów izb Prezesowi Rady Ministrów, co de facto oznaczałoby podporządkowanie finansowego organu nadzoru władzy wykonawczej, której przedstawicielem $\mathrm{w}$ terenie jest przecież wojewoda.

\section{Bibliografia}

Dębowska-Romanowska T., Na dwudziestolecie powstania regionalnych izb obrachunkowych..., w: Samorzą, finanse, nadzór i kontrola. XX-lecie Regionalnych Izb Obrachunkowych, red. R. Krawczyk, M. Stec, Warszawa 2013.

Dolnicki B., Nadzór nad samorzadem terytorialnym, Katowice 1993.

Miemiec M., Miemiec W., Sawicka K., Prawo finansów publicznych sektora samorzadowego, Warszawa 2013.

30 T. Dębowska-Romanowska, Na dwudziestolecie ... s. 16. 
Ofiarska M., Ofiarski Z., Opinie regionalnych izb obrachunkowych jako narzędzie oddziatywania na organy jednostek samorzadu terytorialnego, w: Samorzad, finanse, nadzór i kontrola. XX-lecie Regionalnych Izb Obrachunkowych, red. R Krawczyk, M. Stec, Warszawa 2013.

Pismo Przewodniczącej KRRiO z dnia 2 czerwca, 2017 r., znak: KRRIO$-0718 / \mathrm{I} / 14 / 2017$.

Salachna J., Funkcja ustrojowa regionalnych izb obrachunkowych, Finanse Komunalne 2018, nr 12.

Samorząd, finanse, nadzór i kontrola. XX-lecie Regionalnych Izb Obrachunkowych, red. R. Krawczyk, M. Stec, Warszawa 2013.

Samorzą terytorialny i rozwój lokalny, red. A. Piekara, Z. Niewiadomski, Warszawa 1996.

Skibiński A., Regionalne Izby Obrachunkowe i Samorządowe Kolegia Odwoławcze typowe organy administracji czy wyspecjalizowana administracja wojewódzka, PWSZ IPiA Studia Lubuskie 2008, t. 4.

Tarno J.P., Naczelny Sąd Administracyjny, a wykładnia prawa administracyjnego, Łódź 1997.

Tarno J.P., Dwuinstancyjność w systemie organów samorządu terytorialnego, Miejsce i rola RIO i SKO w systemie samorządu terytorialnego, Ogólnopolska Konferencja Naukowa, Uniwersytet Zielonogórski, Zielona Góra 2005.

Uzasadnienie do odmowy podpisania ustawy przez Prezydenta RP z dnia 12.07.2017 r., http:/ / orka.sejm.gov.pl/Druki8ka.nsf/0/50D05A87AB4A7F4C C1258161002FFFC3/\%24File/1749.pdf [dostęp: 02.01.2017 r.].

Uzasadnienie projektu ustawy o zmianie ustawy o regionalnych izbach obrachunkowych i niektórych innych ustaw, http://www.sejm.gov.pl/Sejm8. nsf/druk.xsp?nr=1409 [dostęp: 4.01.2018 r.].

\section{Streszczenie}

Regionalne izby obrachunkowe stanowią państwowe organy nadzoru i kontroli nad jednostkami samorządu terytorialnego. Ich ustrój oraz zasady funkcjonowania uregulowane zostały w ustawie z dnia 7 października 1992 r. o regionalnych izbach obrachunkowych. Po 25 latach funkcjonowania opracowany został projekt ustawy nowelizującej, który w dniu 8 czerwca 2017 r. został uchwalonych przez Sejm oraz Senat. Przyjęta przez parlament ustawa zakładała szereg zmian w zakresie ustroju oraz organizacji regionalnych izb obrachunkowych. Jednocześnie w ustawie zastosowano rozwiązania dotyczące stosunków pracy dotychczasowych pracowników. W dniu 12 lipca 2017 r. Prezydent Rzeczypospolitej Polskiej, korzystając z przysługującej mu prerogatywy na mocy art. 122 ust. 5 Konstytucji Rzeczypospolitej Polskiej, odmówił podpisania ustawy. 
Niniejsza publikacja stanowi krytyczną analizę przyjętych przez parlament rozwiązań ustawowych, a także uzasadnienie odmowy podpisania ustawy przez Prezydenta RP.

Słowa kluczowe: samorząd lokalny, regionalne izby obrachunkowe, Konstytucja

\title{
CRITICAL ANALYSIS OF THE ACT OF 8 JUNE 2017 ON AMENDING THE ACT ON REGIONAL CHAMBERS OF AUDIT AND CERTAIN OTHER ACTS
}

\begin{abstract}
Sum mary
The Regional Chambers of Audit are financial supervisory authorities for local government units. Their system and organization is regulated by the Act of 7 October 1992 on regional chambers of audit. After 25 years of operation, a draft bill for amending the aforementioned act was created in the Ministry of Internal Affairs. On 8 June 2017, the draft bill was adopted by the Sejm and then by the Senate. The amending provisions introduced significant changes to the system and organization of the regional chambers of audit, and decided about the lawful termination of the employment relationship with personnel employed in the chambers. On July 2017, the President of the Republic of Poland, on the basis of Article 122 (5) of the Constitution of the Republic of Poland, refused to sign the act, and sent it back to be reexamined by the Parliament. This publication involves a critical analysis of the vetoed provisions and the motives for the refusal to sign the Act by the President of the Republic of Poland.
\end{abstract}

Key words: local self-government, regional chambers of audit, Constitution

\section{КРИТИЧЕСКИЙ АНАЛИЗ РЕШЕНИЙ ЗАКОНА ОТ 8 ИЮНЯ 2017 ГОДА О ВНЕСЕНИИ ИЗМЕНЕНИЙ В ЗАКОН О РЕГИОНАЛЬНЫХ СЧЕТНЫХ ПАЛАТАХ И НЕКОТОРЫЕ ДРУГИЕ ЗАКОНЫ}

\section{Резюме}

Региональные счетные палаты являются органами государственного надзора и контроля за органами местного самоуправления. Их система и принципы деятельности регулируются законом от 7 октября 1992 г. о региональных счетных палатах. 25 лет спустя был разработан проект закона о внесении изменений в закон о региональных счетных палатах, который 8 июня 2017 года был принят Сеймом и Сенатом. Закон, принятый 
парламентом, предполагал ряд изменений в политической системе и организации региональных счетных палат. В то же время закон применяет решения, касающиеся трудовых отношений сотрудников этих учреждений. 12 июля 2017 года Президент Республики Польша, осуществляя свою прерогативу по ст. 122 (5) Конституции РП, отказал в подписании закона. Настоящая статья представляет собой критический анализ законодательных решений, принятых парламентом, а также обоснование отказа подписать закон Президентом Республики Польша.

Ключевые слова: местное самоуправление, региональные счетные палаты, Конституция 
